\title{
Multiscale Genetic Structure of Yellowstone Cutthroat Trout in the Upper Snake River Basin
}

\author{
Christine C. Ceggelski* and Matthew R. Campbell \\ Idaho Department of Fish and Game, 1800 Trout Road, Eagle, Idaho 83616, USA
}

\author{
Kevin A. Meyer \\ Idaho Department of Fish and Game, 1414 East Locust Lane, Nampa, Idaho 83686, USA
}

\author{
Madison S. Powell \\ University of Idaho, Center for Freshwater and Salmonid Species at Risk, \\ 3059-F National Fish Hatchery Road, Hagerman, Idaho 83332, USA
}

\begin{abstract}
Populations of Yellowstone cutthroat trout Oncorhynchus clarkii bouvierii have declined throughout their native range as a result of habitat fragmentation, overharvest, and introductions of nonnative trout that have hybridized with or displaced native populations. The degree to which these factors have impacted the current genetic population structure of Yellowstone cutthroat trout populations is of primary interest for their conservation. In this study, we examined the genetic diversity and genetic population structure of Yellowstone cutthroat trout in Idaho and Nevada with data from six polymorphic microsatellite loci. A total of 1,392 samples were analyzed from 45 sample locations throughout 11 major river drainages. We found that levels of genetic diversity and genetic differentiation varied extensively. The Salt River drainage, which is representative of the least impacted migration corridors in Idaho, had the highest levels of genetic diversity and low levels of genetic differentiation. High levels of genetic differentiation were observed at similar or smaller geographic scales in the Portneuf River, Raft River, and Teton River drainages, which are more altered by anthropogenic disturbances. Results suggested that Yellowstone cutthroat trout are naturally structured at the major river drainage level but that habitat fragmentation has altered this structuring. Connectivity should be restored via habitat restoration whenever possible to minimize losses in genetic diversity and to preserve historical processes of gene flow, life history variation, and metapopulation dynamics. However, alternative strategies for management and conservation should also be considered in areas where there is a strong likelihood of nonnative invasions or extensive habitat fragmentation that cannot be easily ameliorated.
\end{abstract}

Assessments of genetic population structure are central to the conservation and management of native fish populations. One of the underlying motivations for these genetic investigations is to evaluate long-term population viability (Allendorf and Waples 1996; Epifanio et al. 2003). Riverine systems are increasingly becoming fragmented as a result of environmental degradation and anthropogenic modifications. These alterations can significantly impact the viability of populations if gene flow is reduced by leading to inbreeding, losses in genetic diversity and, ultimately, to local extirpations through stochastic environmental perturbations (Lande 1993). Elucidating patterns of genetic diversity and genetic differentiation throughout a species' range can guide management by determining the spatial scale at which reproductively isolated populations exist and the genetic relationships of

\footnotetext{
* Corresponding author: ccegelski@idfg.idaho.gov
}

Received January 3, 2005; accepted November 28, 2005 Published online May 30, 2006 populations. This information can help identify management units, populations in need of genetic supplementation and candidate source populations, and estimate the probability of natural recolonization in fragmented habitats as well as help provide estimates of population abundance and status.

Management and conservation of genetic diversity within a species depends upon the scale and pattern of genetic structure. Little genetic differentiation among populations continuously distributed across a broad scale (e.g., drainage) as a result of high levels of gene flow suggests that conservation and management can take a regional approach and protect a few key populations to maintain genetic diversity within the species (Allendorf and Leary 1988). Conversely, substantial genetic differentiation among populations as a result of limited genetic exchange suggests that many local populations are needed to represent and maintain genetic diversity (Kanda and Allendorf 2001). Within the complex of cutthroat trout Oncorhynchus clarkii, the minimum spatial scale of genetic differen- 
tiation varies widely across subspecies. This may be due to the variety of life history patterns expressed (Neville et al., in press), differences in availability of suitable habitat, and temporal changes in climate, population abundance, and landscape features (Rieman and Dunham 2000). Since patterns of genetic structure are not similar for all cutthroat trout subspecies, each subspecies needs to be independently evaluated in both continuously distributed and fragmented landscapes to accurately describe how genetic variation is partitioned.

Yellowstone cutthroat trout $O$. c. bouvierii is one of 13 extant subspecies of cutthroat trout native to North America (Behnke 1992). The historical range of Yellowstone cutthroat trout includes the Snake River basin upstream from Shoshone Falls on the western side of the continental divide and the Yellowstone River drainage from its headwaters to the Tongue River on the eastern side of the divide (Behnke 1992). Similar to other native trout subspecies, the historical distribution and abundance of Yellowstone cutthroat trout has declined as a result of introductions of nonnative fishes, environmental fragmentation, and past human overharvest (Thurow et al. 1988; Varley and Gresswell 1988; Gresswell 1995). Recent concerns regarding its decline led to a petition to list the species as threatened under the Endangered Species Act. The petition was denied in 2003 (USFWS 2003); however, it remains a "species of special concern" by the U.S. Fish and Wildlife Service, U.S. Forest Service, American Fisheries Society, and all states throughout its historical range (Idaho, Montana, Nevada, Utah, and Wyoming).

Yellowstone cutthroat trout exhibit both migratory and resident life history forms that may coexist in the same population (Thurow et al. 1988). Yellowstone cutthroat trout typically utilize smaller tributaries for spawning and juvenile rearing. Resident fish stay in these tributaries, while migratory fish emigrate as fry or juveniles into larger tributaries, lakes, or reservoirs (Benson 1960). Although migratory cutthroat trout may leave their natal tributaries, strong homing tendencies to return to natal streams to spawn have been documented (Miller 1954; Ball 1955; LaBar 1971; Clancy 1988). Dispersal occurs in salmonids when individuals migrate to areas other than their natal tributaries to spawn (Dingle 1996). The magnitude and frequency of dispersal is unknown for many salmonids as well as the classification of most individuals and populations to a specific migratory type (Meka et al. 2003). Although dispersal can promote interaction among anadromous populations, dispersal does not necessarily result in gene flow, and any estimation of dispersal rates may upwardly bias gene flow estimates (Verhulst and van Eck 1996; Wenburg and Bentzen
2001). An understanding of migratory patterns, levels of gene flow between populations, and the minimum spatial scale of genetic structuring is useful for fishery management.

Although microsatellite analyses have been performed on many anadromous salmonids (Banks et al. 2000; King et al. 2001; Olsen et al. 2003; Beacham et al. 2004), few cutthroat trout subspecies have been genetically studied with this approach. Previous research investigating the genetic population structure of cutthroat trout subspecies (coastal cutthroat trout O.C. clarkii: Wenburg et al. 1998; Wenburg and Bentzen 2001; westslope cutthroat trout $O$. c. lewisii: Taylor et al. 2003; Lahontan cutthroat trout O. c. henshawii: Neville-Arsenault 2003) has revealed strong genetic differentiation among populations within drainages. However, the geographic scale for genetic differentiation varies from many independent populations occupying segments of the same stream (Young et al. 2004) to major streams within drainages (Wenburg and Bentzen 2001).

A different pattern of genetic structure has been reported for Yellowstone cutthroat trout. Using five polymorphic allozyme loci, Allendorf and Leary (1988) and Leary et al. (1995) concluded that there was minimal genetic differentiation detected among 59 populations sampled within the Yellowstone River basin and that Yellowstone cutthroat trout are structured at the river drainage level. While allozyme data have been useful in detecting fine-scale differences in other salmonids (Knudsen et al. 2002; Spruell et al. 2003), genetic differences have been detected among populations with microsatellite data that were not previously detected with allozyme data (Hughes and Queller 1993; Tessier et al. 1995; but see Hedrick 1999). Broad-scale information about how genetic diversity is partitioned outside of the Yellowstone River drainage (in occupied drainages within the upper Snake River basin) also remains uncharacterized. Therefore, the genetic structure of Yellowstone cutthroat trout remains relatively unclear.

The primary objective of this study was to provide comprehensive information regarding the patterns of genetic diversity and genetic differentiation present within Yellowstone cutthroat trout using polymorphic microsatellite data. Samples $(n=1,392)$ were collected from 44 Yellowstone cutthroat trout sample locations within 10 major river drainages in the upper Snake River basin and one location within the Yellowstone River basin. These data were used to assess genetic population structure among the major river drainages as well as within drainages to determine the extent and scale of genetic differentiation. We also wanted to compare patterns of within-drainage differentiation to determine how gene flow and genetic drift have 
influenced population structure (Hutchinson and Templeton 1999), as patterns of isolation by distance have been previously reported for other salmonids (Wenburg et al. 1998). Results are compared with other cutthroat trout subspecies, and recommendations for management and future research needs are identified.

\section{Methods}

Sampling and DNA extraction.-During 19992003, 2,990 tissue samples were collected from 96 sample sites by Idaho Department of Fish and Game (IDFG) personnel as part of a larger study investigating native salmonid abundance in the upper Snake River basin. Samples were also collected to investigate introgression of rainbow trout $O$. mykiss; therefore, fin clips were randomly collected from all salmonid species. A total of 44 sample sites were subsampled for genetic analyses in 10 major river drainages. Two of the sample locations were collected in multiple years (Harkness Creek and Tincup Creek) to test for temporal stability in allele frequencies. In addition, one location from the Yellowstone River basin was included as a reference. Sample sizes and locations of sample sites are presented in Table 1 and Figure 1. Samples were stored in $100 \%$ nondenatured ethanol until DNA extraction. The DNA was extracted following a saltchloroform method described by Paragamian et al. (1999).

Hybridization.-All samples were first screened to distinguish Yellowstone cutthroat trout from rainbow trout and hybrids. One diagnostic mitochondrial DNA marker, NADH dehydrogenase $2(N D-2)$ digested with RsaI (Campbell et al. 2002), and three diagnostic nuclear markers (recombination activation gene Rag $3^{\prime}$; Baker et al. 2002] digested with DdeI, Occ38 [Ostberg and Rodriguez 2002, 2004], and Occ42 [Ostberg and Rodriguez 2002, 2004]) were amplified and digested (if applicable) following the methodology described by Campbell et al. (2002) and Ostberg et al. (2004). Fragments were separated by $3 \%$ agarose-synergel electrophoresis.

The subsample of sites to be used in the genetic population structure analysis was chosen to avoid hybrid populations, but where they were genetically detected all fish with genotypes indicative of rainbow trout and hybrids were subsequently removed from the data set $(n=20)$.

Microsatellite amplification.-Six polymorphic microsatellite loci were amplified with the use of fluorescently labeled primers: Ogo4 (Olsen et al. 1998), OMM1036 (Rexroad et al. 2002), Fgt3 (Sakamoto et al. 1994), Ots107 (Nelson and Beacham 1999), Ocll (Condrey and Bentzen 1998), and Ssa85 (Wenburg and Bentzen 2001). Two duplex and two single polymerase chain reactions (PCR) were performed. Duplex 1 consisted of primers $O g 04(0.40 \mu \mathrm{M})$ and $O M M 1036(0.50 \mu \mathrm{M})$. A $20-\mu \mathrm{L}$ PCR reaction was performed with $1 \mu \mathrm{L}$ of genomic DNA (unknown concentration), $2.0 \mathrm{mM}$ of each dNTP (deoxynucleotide triphosphate), $2.5 \mathrm{mM}$ of $\mathrm{MgCl}_{2}, 0.80 \mu \mathrm{g} / \mu \mathrm{L}$ bovine serum albumin (New England Biolabs), 1X AmpliTaq buffer (Applied Biosystems), and $0.75 \mathrm{U}$ of AmpliTaq polymerase (Applied Biosystems). Cycling was performed with a PTC-100 (MJ Research) with the following profile: $95^{\circ} \mathrm{C}$ for $2 \mathrm{~min}, 35$ cycles of $30 \mathrm{~s}$ at $95^{\circ} \mathrm{C}, 30 \mathrm{~s}$ at $59^{\circ} \mathrm{C}$, and $40 \mathrm{~s}$ at $72^{\circ} \mathrm{C}$, and a final 30 -min extension at $72^{\circ} \mathrm{C}$. Duplex 2 consisted of primers $\mathrm{Fgt3}$ $(0.30 \mu \mathrm{M})$ and Ots107 $(0.10 \mu \mathrm{M})$. The PCR reaction conditions and profile were identical to duplex 1 except for a $50^{\circ} \mathrm{C}$ annealing temperature. Both $\operatorname{Ocll}(1.0 \mu \mathrm{M})$ and Ssa85 $(0.4 \mu \mathrm{M})$ were amplified alone with identical PCR reaction conditions and profile to duplex 1 , except for $60^{\circ} \mathrm{C}$ and $56^{\circ} \mathrm{C}$ annealing temperatures, respectively. All PCR products were electrophoresed with an ABI 310 automated sequencer (Applied Biosystems) platform. The PCR products from duplex 1, Ssa85, and Ocll were electrophoresed together, and PCR products from duplex 2 were electrophoresed together. Fragments were sized against GS500 ROX size standard (Applied Biosystems) with GENESCAN and GENOTYPER software (Applied Biosystems).

Microsatellite data analyses.-Each population was tested for Hardy-Weinberg equilibrium and linkage disequilibrium with GENEPOP on the Web (Raymond and Rousset 1995). A sequential Bonferroni correction was used to adjust significance for multiple comparisons (Rice 1989). An $\alpha$ value of 0.05 was chosen for statistical significance for all analyses.

Genetic diversity was measured by the number of alleles per locus $(A)$, observed heterozygosity $\left(H_{o}\right)$, and expected heterozygosity $\left(H_{e}\right)$ with FSTAT (Goudet 2001). A rarefaction option performed by FSTAT was used to account for unequal sample sizes. Corrected estimates of allelic diversity $\left(R_{t}\right)$ were obtained based upon the smallest sample size of this study $(n=16)$. Statistical differences in genetic diversity were estimated two ways: (1) a permutation approach of FSTAT was used to compare genetic diversity estimates among drainages, and (2) differences among sample sites within drainages were evaluated with nonparametric pairwise Wilcoxon signed-ranks comparisons.

Large-scale genetic structuring was evaluated at the drainage level. Populations were grouped according to drainage location (Table 1). An analysis of molecular variance (AMOVA) was performed to determine how genetic variation was hierarchically partitioned (Excoffier et al. 1992). The percentage of the total variation within populations, among populations within 
TABLE 1.-Genetic diversity estimates for Yellowstone cutthroat trout populations. Abbreviations are as follows: $N=$ sample size; $H_{e}=$ average expected heterozygosity across six loci; $A=$ average number of alleles across six loci; $R_{t}=$ average allelic richness across six loci. Asterisks indicate temporal replicates and daggers populations in which hybrids were identified.

\begin{tabular}{|c|c|c|c|c|c|c|c|}
\hline Drainage & Location & Site number ${ }^{\mathrm{a}}$ & Year & $N$ & $H_{e}$ & $A$ & $R_{t}$ \\
\hline Henrys Fork & Tyghee Creek & 1 & 1999 & 24 & 0.38 & 2.67 & 2.58 \\
\hline \multirow{5}{*}{ Teton River } & North Moody Creek $\dagger$ & 2 & 2000 & 30 & 0.64 & 4.83 & 4.39 \\
\hline & Canyon Creek $\dagger$ & 3 & 1999 & 30 & 0.65 & 8.17 & 6.96 \\
\hline & South Fork Badger Creek $\dagger$ & 4 & 2000 & 29 & 0.73 & 7.00 & 6.25 \\
\hline & Mahogany Creek & 5 & 2000 & 31 & 0.55 & 3.67 & 3.45 \\
\hline & Mike Harris Creek $\dagger$ & 6 & 2000 & 30 & 0.58 & 5.33 & 4.51 \\
\hline \multirow[t]{7}{*}{ South Fork Snake River } & Garden Creek & 7 & 2002 & 28 & 0.6 & 5.50 & 4.91 \\
\hline & Fall Creek $\dagger$ & 8 & 2000 & 29 & 0.5 & 5.00 & 4.31 \\
\hline & West Pine Creek $\dagger$ & 9 & 2000 & 25 & 0.81 & 9.00 & 8.12 \\
\hline & North Fork Rainey Creek & 10 & 1999 & 31 & 0.76 & 9.00 & 8.04 \\
\hline & Low Palisades Creek & 11 & 2002 & 31 & 0.74 & 7.83 & 6.67 \\
\hline & North Fork Palisades Creek & 12 & 2002 & 23 & 0.59 & 4.00 & 3.92 \\
\hline & Corral Canyon & 13 & 2002 & 29 & 0.74 & 6.50 & 6.16 \\
\hline \multirow[t]{9}{*}{ Salt River } & McCoy Creek & 14 & 2000 & 31 & 0.74 & 9.83 & 8.36 \\
\hline & Fish Creek & 15 & 1999 & 31 & 0.78 & 8.67 & 7.44 \\
\hline & Barnes Creek & 16 & 2000 & 31 & 0.76 & 9.67 & 8.08 \\
\hline & Clear Creek & 17 & 2000 & 31 & 0.72 & 9.50 & 8.08 \\
\hline & Tincup Creek & 18 & 2000 & 31 & 0.78 & 9.67 & 8.68 \\
\hline & Tincup Creek & $18^{*}$ & 2003 & 31 & 0.77 & 9.83 & 8.69 \\
\hline & South Fork Tincup Creek & 19 & 1999 & 31 & 0.76 & 9.67 & 7.90 \\
\hline & Horse Creek & 20 & 2000 & 31 & 0.76 & 8.83 & 7.67 \\
\hline & Crow Creek & 21 & 2000 & 31 & 0.73 & 8.17 & 6.93 \\
\hline \multirow[t]{5}{*}{ Willow Creek } & Willow Creek & 22 & 1999 & 31 & 0.72 & 7.83 & 6.94 \\
\hline & Mill Creek & 23 & 1999 & 26 & 0.68 & 7.17 & 6.29 \\
\hline & Sellars Creek & 24 & 1999 & 31 & 0.73 & 8.33 & 7.05 \\
\hline & South Fork Sellars Creek & 25 & 2001 & 30 & 0.75 & 9.00 & 7.78 \\
\hline & Lava Creek & 26 & 1999 & 31 & 0.73 & 6.83 & 5.91 \\
\hline \multirow[t]{3}{*}{ Blackfoot River } & Miner Creek & 27 & 2000 & 31 & 0.61 & 6.17 & 5.39 \\
\hline & Rawlins Creek $\dagger$ & 28 & 2000 & 29 & 0.64 & 6.17 & 5.5 \\
\hline & Blackfoot Creek $\dagger$ & 29 & 1999 & 30 & 0.60 & 6.50 & 5.69 \\
\hline \multirow[t]{8}{*}{ Portneuf River } & Gibson Jack Creek & 30 & 2003 & 29 & 0.61 & 5.67 & 5.04 \\
\hline & Bell Marsh Creek & 31 & 2000 & 31 & 0.68 & 7.83 & 6.90 \\
\hline & Goodenough Creek & 32 & 2003 & 31 & 0.67 & 6.17 & 5.19 \\
\hline & Rapid Creek $\dagger$ & 33 & 2000 & 30 & 0.65 & 8.67 & 7.41 \\
\hline & Inman Creek & 34 & 2000 & 30 & 0.72 & 7.17 & 6.34 \\
\hline & Robbers Roost Creek & 35 & 2000 & 31 & 0.67 & 6.17 & 5.38 \\
\hline & Harkness Creek & 36 & 2000 & 30 & 0.71 & 6.33 & 5.93 \\
\hline & Harkness Creek & $36^{*}$ & 2003 & 31 & 0.73 & 6.33 & 6.01 \\
\hline \multirow[t]{6}{*}{ Raft River } & Cottonwood Creek & 37 & 2001 & 30 & 0.69 & 6.00 & 5.45 \\
\hline & Green Creek & 38 & 2001 & 30 & 0.64 & 6.00 & 5.36 \\
\hline & New Canyon Creek & 39 & 2001 & 30 & 0.49 & 4.50 & 3.87 \\
\hline & Almo Creek & 40 & 1999 & 24 & 0.47 & 3.50 & 3.35 \\
\hline & Johnson Creek & 41 & 2001 & 31 & 0.45 & 4.17 & 3.69 \\
\hline & Basin Creek & 42 & 2001 & 30 & 0.64 & 4.83 & 4.54 \\
\hline Goose Creek & Ecklund Creek & 43 & 2001 & 31 & 0.62 & 6.67 & 5.62 \\
\hline Dry Creek & E. F. Dry Creek & 44 & 2003 & 31 & 0.66 & 6.00 & 5.31 \\
\hline Yellowstone River & Yellowstone Lake & 45 & 2000 & 24 & 0.67 & 7.83 & 6.99 \\
\hline
\end{tabular}

${ }^{a}$ See Figure 1.

drainages, and among drainages was calculated with Arlequin (Schneider et al. 2000). An unrooted neighbor-joining (NJ) tree using Cavalli-Sforza and Edwards' (1967) chord distance $\left(D_{c e}\right)$ was used to display the clustering relationship among populations with the software Populations (Langella 2001) and TREEVIEW (Page 1996). One thousand bootstrap replicates were performed to evaluate tree topology.

Fine-scale genetic structuring was evaluated among populations within drainages. Only one population was sampled in four of the drainages (Dry Creek, Goose Creek, Henrys Fork, Yellowstone River) and could not be included at this scale due to a lack of nearby populations for comparisons. Pairwise genetic differentiation $\left(F_{\mathrm{ST}}\right)$ estimates (Weir and Cockerham 1984) were generated with the software Arlequin (Schneider et al. 2000) with significance based upon a permutation process. A sequential Bonferroni correction was used to adjust significance for multiple comparisons (Rice 1989). Confidence intervals $(95 \%)$ for $F_{\mathrm{ST}}$ estimates were also generated by bootstrap sampling over loci with FSTAT (Goudet et al. 1996). In the two locations where sampling was conducted in multiple years, temporal fluctuations in allele frequencies were tested 


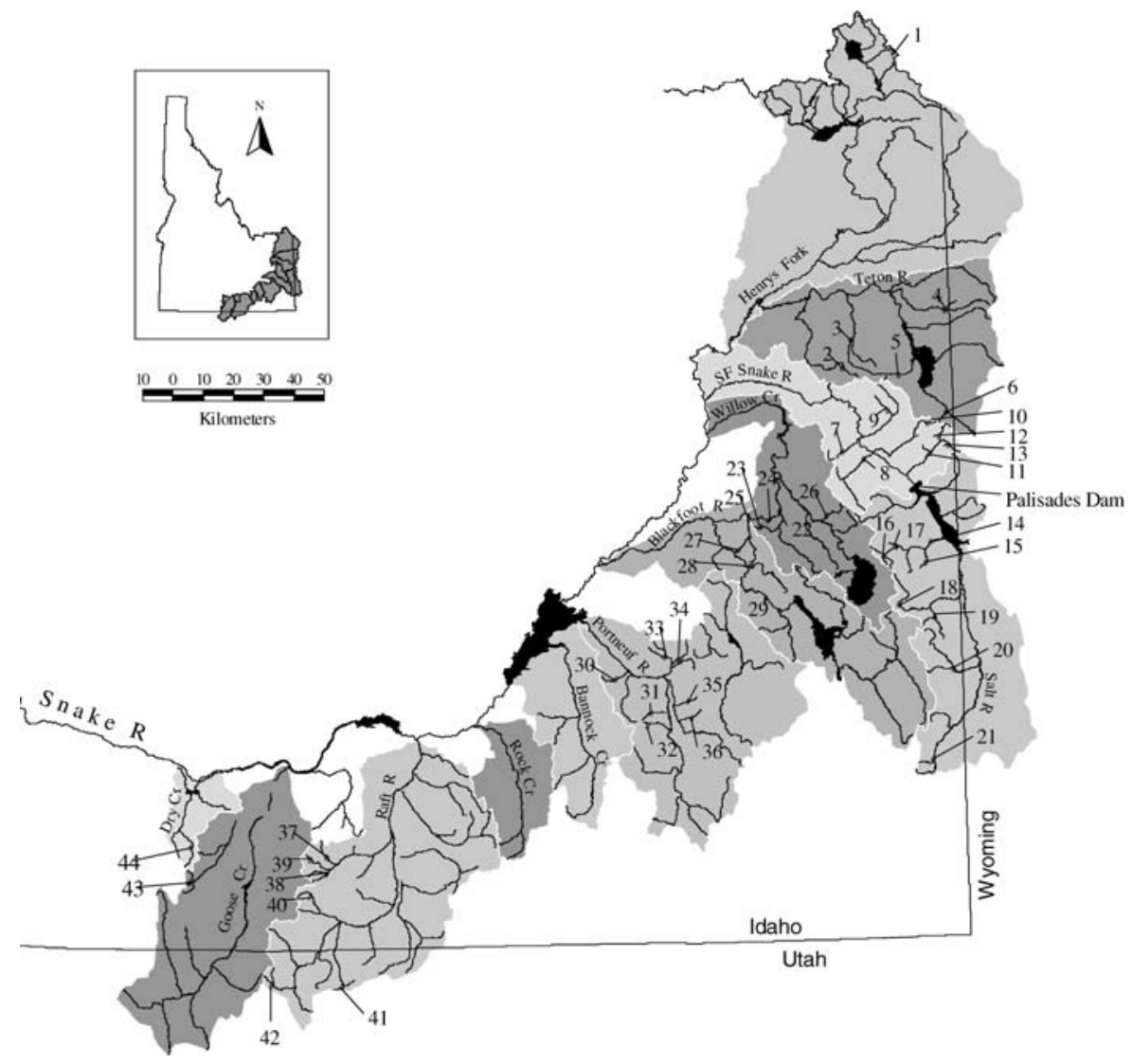

FIGURE 1.- Sampling locations of Yellowstone cutthroat trout in the upper Snake River basin in Idaho, 1999-2003. Sites are numbered according to drainage locality (see Table 1 for site names).

by examining genotypic distributions with GENEPOP on the Web (Raymond and Rousset 1995).

To test for isolation by distance, the relationship between genetic $\left(F_{\mathrm{ST}}\right)$ and geographic (fluvial) distance was investigated with a Mantel test (Mantel 1967). Geographic distance was measured in kilometers following stream networks for each pair of sampling locations with a program written for ArcView 3.2. A regression of $F_{\mathrm{ST}} /\left(1-F_{\mathrm{ST}}\right)$ on the logarithm of geographic distance for all population pairs within drainages was conducted with GENEPOP on the Web (Raymond and Rousset 1995).

The Bayesian method of STRUCTURE (Pritchard et al. 2000) was also used to determine levels of finescale structuring without any prior knowledge of population origin and assign individuals to inferred population clusters $(K)$. Five independent runs of $K=$ 1-45 were run at 100,000 Markov-chain Monte Carlo (MCMC) repetitions and 100,000 burn-in. The most probable number of $K$ was then chosen as having the highest $\log$-likelihood value $\left(\log _{e}\right.$ probability of the data). Individuals were assigned to a population cluster or multiple population clusters based upon their multilocus genotype.

\section{Results}

Twenty hybrids were detected in nine of the sampled populations. The percentage of rainbow trout alleles out of the total number of alleles sampled was $1 \%$ in seven of the populations (Blackfoot River, Canyon Creek, Fall Creek, North Moody Creek, Mike Harris Creek, Rapid Creek, South Fork Badger Creek), 6\% in Rawlins Creek, and 7\% in West Pine Creek. The identified hybrids were removed and West Pine Creek and Rawlins Creek were not included in the summaries for drainage-wide levels of diversity since the possible presence of nonnative alleles may inflate estimates of average heterozygosity and allelic richness.

Tests for Hardy-Weinberg equilibrium revealed that genotypes were in expected proportions, except for 41 of the 282 tests. While these results are higher than expected by chance (14.1 tests expected from type I 


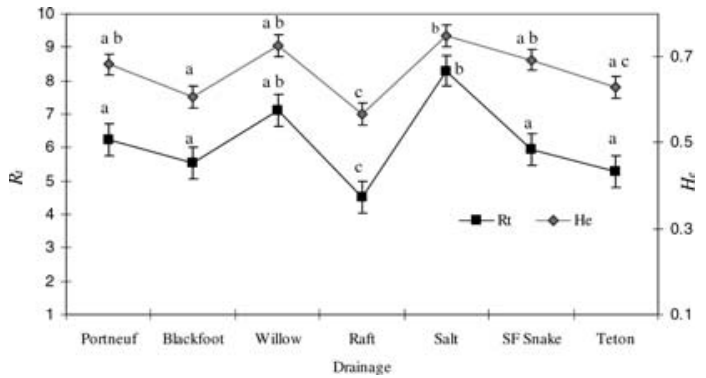

Figure 2.-Average expected heterozygosity $\left(H_{e}\right)$ and average allelic richness $\left(R_{t}\right)$ of Yellowstone cutthroat trout from seven drainages in the upper Snake River basin in Idaho, 1999-2003. Standard error bars are displayed for each value; values with common letters are not significantly different.

error of 0.05 ), none of the tests were associated with a particular locus and no more than 2 tests were rejected per population except for three populations (Inman Creek, 4 tests rejected; Crow Creek, 3 tests rejected; Gibson Jack Creek, 4 tests rejected). A total of 675 tests for linkage disequilibrium were performed and 42 of the tests were rejected at $\alpha=0.05$, which also was slightly higher than expected by chance (34 expected from type I error of 0.05 ). No more than 6 tests clustered around a particular locus pair within the 47 populations sampled, indicating that these loci were not closely linked. Hybridization can lead to deviations from Hardy-Weinberg expectations and linkage disequilibrium (Roques et al. 2001). However, none of the significant tests clustered within populations where hybrids were identified.

\section{Genetic Diversity}

The number of alleles per locus ranged from 8 alleles (Ocll) to 32 alleles $(\mathrm{Fgt} 3)$. Genetic diversity varied widely within populations and within drainages (Table 1). Expected heterozygosity ranged from 0.38 in Tyghee Creek to 0.81 in West Pine Creek and allelic richness ranged from 2.58 alleles in Tyghee Creek to 8.69 alleles in Tincup Creek. The permutation test revealed that the Salt River drainage had significantly higher levels of average expected heterozygosity and allelic richness, while the Raft River drainage had the lowest levels of heterozygosity and allelic richness (Figure 2). No significant differences in genetic diversity were apparent for the other drainage comparisons.

Statistical differences in genetic diversity levels were detected within drainages with the Wilcoxon signedranks tests. Both Canyon Creek and South Fork Badger Creek had higher levels of allelic richness and heterozygosity compared with other populations sam- pled within the Teton River drainage (Table 1). In the Portneuf River drainage, only Robbers Roost Creek and Gibson Jack Creek had lower levels of allelic richness compared with Inman Creek. In the Willow Creek drainage, Lava Creek had lower levels of allelic richness compared with South Fork Sellars Creek and Willow Creek, while Mill Creek had lower heterozygosity levels than South Fork Sellars Creek. In the Raft River drainage, Cottonwood Creek and Green Creek had higher levels of allelic richness and heterozygosity compared with the other sampled populations, and in the South Fork Snake River drainage, West Pine Creek, Corral Canyon, and North Fork Rainey Creek had higher levels of allelic richness and heterozygosity compared with Garden Creek and Fall Creek.

\section{Genetic Population Structure}

Drainage-wide differences in genetic variation were depicted with an NJ tree using Cavalli-Sforza and Edwards' (1967) chord distance (Figure 3). All of the populations clustered with other populations from the same river drainage except for North Fork Rainey Creek, West Pine Creek, Mahogany Creek, and Mike Harris Creek, revealing genetic similarity among populations within drainages and differences among drainages. The AMOVA analysis indicated that $8 \%$ of the molecular variance was explained by grouping the major drainages, $6 \%$ of the molecular variance was partitioned among populations within drainages, and $81 \%$ of the molecular variance was partitioned within populations.

The Bayesian analysis of STRUCTURE was not able to clearly infer the number of population clusters in the data set when all of the sampling locations were run together. Figure 4 shows the log likelihood for each value of $K$ along with alpha values. While $K=22 \mathrm{had}$ the highest log likelihood and may closely approximate the actual number of distinct population clusters, an asymptote was reached at $K=16$, indicating difficulty in determining $K$. At $K=22$, all 11 drainages were separated into unique clusters. STRUCTURE was conducted separately for each of the drainages to resolve genetic structuring within drainages. The number of population clusters identified in this analysis was 25 , and similar relationships were detected with $K$ $=22$. The results are summarized for each drainage in Figure 5.

Although multiple geographic locations were sampled within the Blackfoot River and Salt River drainages, the Bayesian analysis suggested that each of these drainages constituted a single population cluster. In the Teton River drainage, four clusters were identified (Figure 5a). Individuals sampled in Canyon Creek were assigned to the same cluster as those from 


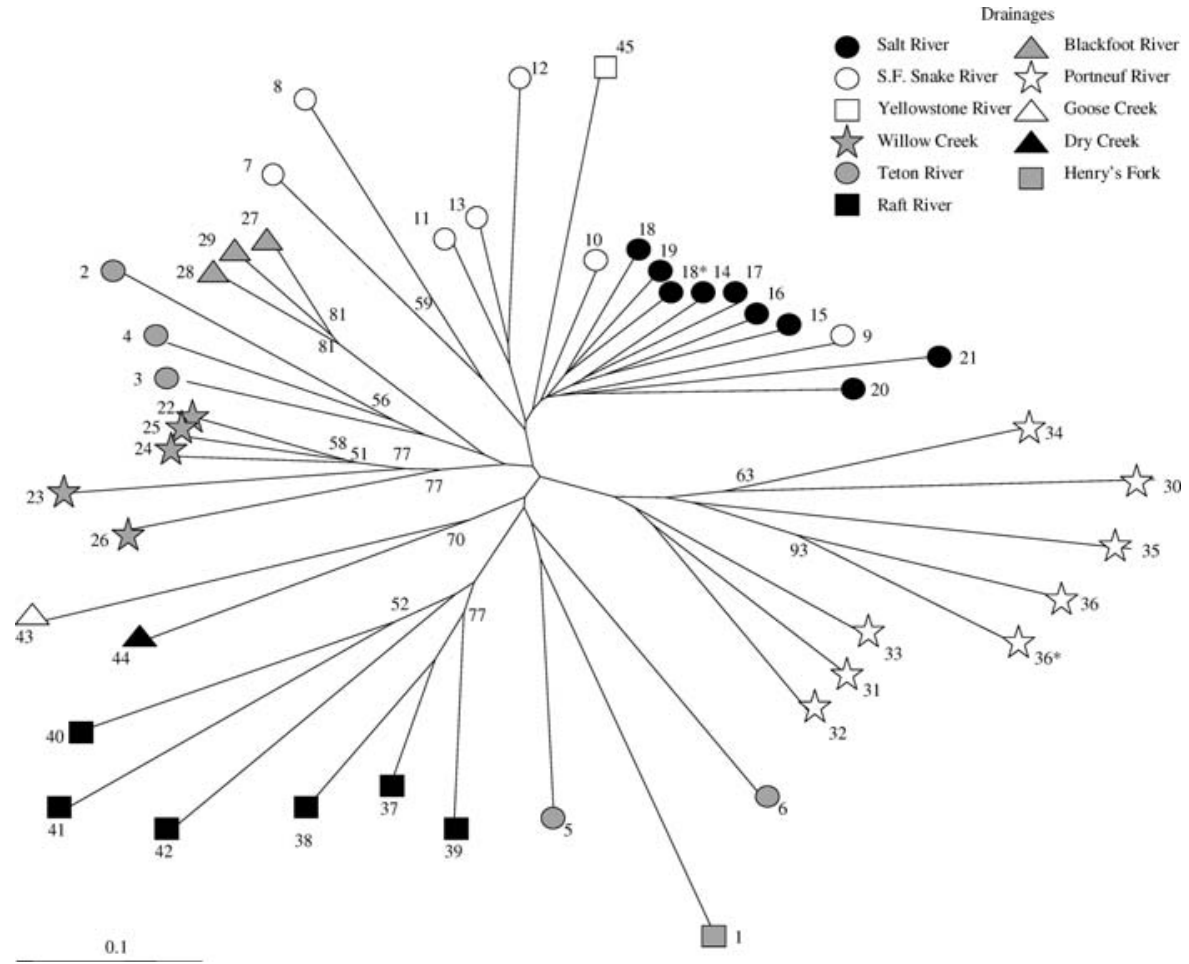

FIGURE 3.-Unrooted neighbor-joining dendrogram of the genetic relationships among 47 Yellowstone cutthroat trout populations from the upper Snake and Yellowstone River basins, 1999-2003, based on Cavalli-Sforza and Edwards (1967) chord distance. Populations are listed in Table 1. The numbers at branch points are bootstrap percentages from 1,000 replicates; only bootstrap values greater than $50 \%$ are presented.

South Fork Badger Creek and North Moody Creek, while Mahogany Creek and Mike Harris Creek had a large proportion of membership $(q>0.90)$ assigned to unique clusters. In the South Fork Snake River drainage, four population clusters were identified (Figure 5b). Fall Creek and Garden Creek had a large proportion of membership $(q>0.79)$ assigned to unique clusters, and admixture was detected between Corral Canyon, lower Palisades Creek, and North Fork Palisades Creek, and between North Fork Rainey Creek, West Pine Creek, and Corral Canyon. In the Willow Creek drainage, two clusters were identified (Figure 5c). Lava Creek had the highest proportion of its membership in a cluster separate from the other

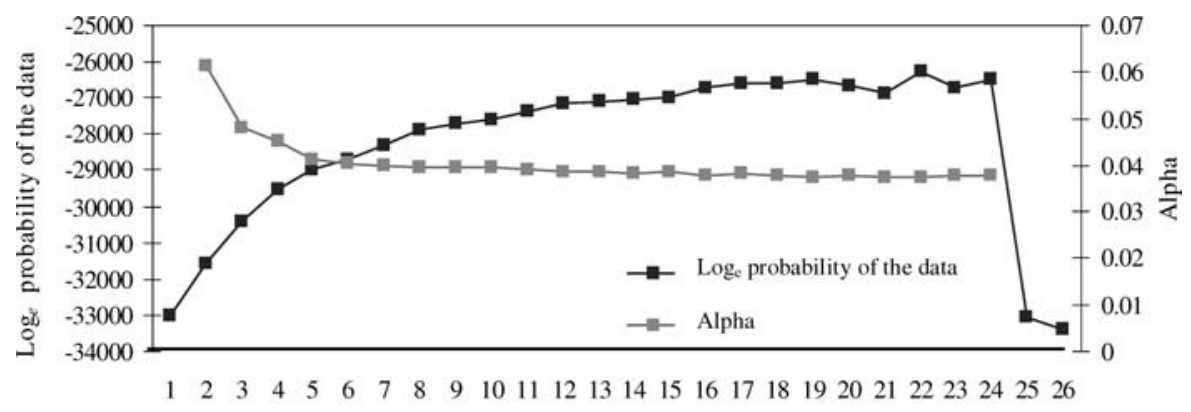

K

FIGURE 4.-Bayesian clustering results of the most likely number of genetic clusters $(K)$ produced by STRUCTURE. The $\log _{e}$ probability of the data and alpha value (degree of admixture) are graphed for $K=1-26$ for 47 Yellowstone cutthroat trout populations from the upper Snake River basin in Idaho, 1999-2003. 


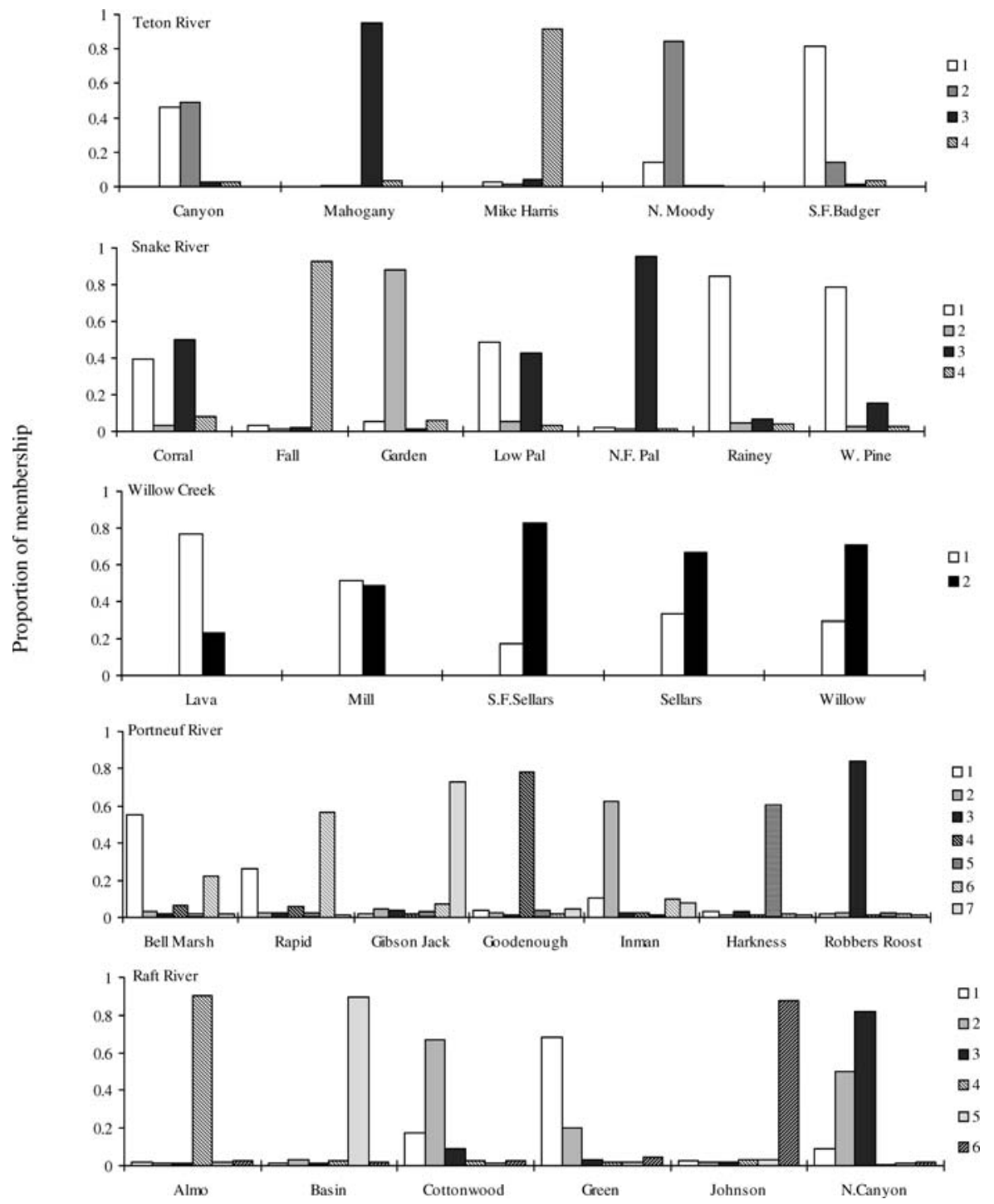

FIGURE 5.-Summary of the clustering results of STRUCTURE for $K=25$. Proportional membership of Yellowstone cutthroat trout sample collections in the identified genetic clusters for each upper Snake River basin drainage, 1999-2003. The number of clusters identified in each drainage ranged from 2 to 7.

sampled populations, but admixture was evident among all sampling locations. In the Portneuf River drainage (Figure 5d) and Raft River drainage (Figure $5 \mathrm{e})$, the most likely number of clusters agreed with the number of sampled populations, but some admixture was detected between Rapid Creek and Bell Marsh Creek and between Cottonwood Creek and Green Creek.

Genetic differentiation among populations within drainages corresponded with the identified genetic clusters. The $F_{\mathrm{ST}}$ estimates were lowest in the
Blackfoot River drainage (0.003 between Rawlins Creek and Blackfoot River to 0.01 between Blackfoot River and Miner Creek) and highest in the Raft River drainage $(0.42$ between New Canyon Creek and Johnson Creek) and reflect different degrees of connectivity within drainages (Table 2). In the Salt River drainage, all pairwise $F_{\mathrm{ST}}$ estimates were lower than 0.06 except for comparisons with Crow Creek $\left(F_{\mathrm{ST}}=0.03-0.08\right)$, and in the Willow Creek drainage all pairwise $F_{\mathrm{ST}}$ estimates were lower than 0.03 except for comparisons with Lava Creek $\left(F_{\mathrm{ST}}=0.05-0.06\right)$. In 
TABLE 2.-Average levels of genetic differentiation for Yellowstone cutthroat trout populations sampled in different drainages, as measured by $F_{\mathrm{ST}}$ values (95\% confidence intervals in parentheses), the range of pairwise $F_{\mathrm{ST}}$ estimates observed, and the range of geographic distances separating populations within drainages. Hydrologic integrity values are listed for each drainage (Van Kirk and Benjamin 2001).

\begin{tabular}{|c|c|c|c|c|c|c|c|}
\hline Metric & $\begin{array}{l}\text { Blackfoot } \\
\text { River }\end{array}$ & $\begin{array}{l}\text { Portneuf } \\
\text { River }\end{array}$ & $\begin{array}{l}\text { Raft } \\
\text { River }\end{array}$ & $\begin{array}{c}\text { Salt } \\
\text { River }\end{array}$ & $\begin{array}{l}\text { South Fork } \\
\text { Snake River }\end{array}$ & $\begin{array}{l}\text { Teton } \\
\text { River }\end{array}$ & $\begin{array}{l}\text { Willow } \\
\text { Creek }\end{array}$ \\
\hline Average $F_{\mathrm{ST}}$ & $\begin{array}{c}0.008 \\
(-0.002 \text { to }+0.02)\end{array}$ & $\begin{array}{c}0.15 \\
(0.10-0.23)\end{array}$ & $\begin{array}{c}0.18 \\
(0.15-0.21)\end{array}$ & $\begin{array}{c}0.02 \\
(0.01-0.03)\end{array}$ & $\begin{array}{c}0.12 \\
(0.10-0.14)\end{array}$ & $\begin{array}{c}0.21 \\
(0.16-0.26)\end{array}$ & $\begin{array}{c}0.03 \\
(0.01-0.05)\end{array}$ \\
\hline Range of $F_{\mathrm{ST}}$ & $0.00-0.01$ & $0.05-0.23$ & $0.06-0.29$ & $0.0-0.07$ & $0.02-0.19$ & $0.05-0.29$ & $0.0-0.06$ \\
\hline Distance among sites $(\mathrm{km})$ & 13-33 & $9-58$ & $10-142$ & $8-140$ & $7-61$ & $37-214$ & 6-64 \\
\hline Hydrologic integrity (\%) & 24 & 23 & 33 & 84 & 73 & 67 & 43 \\
\hline
\end{tabular}

the Portneuf River, Teton River, and Raft River drainages, $F_{\mathrm{ST}}$ estimates ranged from 0.05 (between Rapid Creek and Bell Marsh Creek and between Canyon Creek and South Fork Badger Creek) and 0.06 (between Cottonwood Creek and Green Creek) to 0.23 (between Gibson Jack Creek and Rapid Creek) and 0.29 (between North Moody Creek and Canyon Creek and between New Canyon Creek and Almo Creek). Out of the 860 pairwise $F_{\text {ST }}$ comparisons performed, only 30 were nonsignificant after Bonferroni adjustments for multiple tests. Nonsignificant $F_{\mathrm{ST}}$ estimates were all less than 0.02 and were observed among the following populations: South Fork Sellars Creek, Sellars Creek, Willow Creek, and Mill Creek in the Willow Creek drainage; Blackfoot River, Rawlins Creek, and Miner Creek in the Blackfoot River drainage; and North Fork Palisades Creek, Clear Creek, North Fork Rainey Creek, South Fork Tincup Creek, Horse Creek, McCoy Creek, Tincup Creek, Fish Creek, West Pine Creek, Corral Canyon, and Barnes Creek in the Salt River and South Fork Snake River drainages.

Mantel tests for isolation by distance failed to reject the null hypothesis of no association between genetic and geographic distance in all of the drainages $(P>$ $0.05)$, except for the Salt River drainage $(P=0.003)$ and Willow Creek drainage $(P=0.03)$. In these drainages, there is a positive relationship between genetic distance and geographic distance. The scatterplots revealed that gene flow is more influential than genetic drift at shorter distances and that genetic drift is more influential as populations become more geographically separated (Figure 6). In the Blackfoot River, gene flow is more influential than genetic drift at all distances, resulting in panmixia. In the Teton River, Raft River, and Portneuf River drainages, genetic drift was more influential than gene flow. The resulting pattern is one in which there is a wide degree of scatter across all geographic distances (Figure 6).

Temporal stability of allele frequencies was tested in two sample locations. Tests for genotypic differentiation revealed no significant temporal change in allele frequencies for Tincup Creek $(P=0.08)$. A significant temporal change in allele frequencies was detected for Harkness Creek $(P=0.04)$; however, these sample collections still grouped together on the NJ tree (Figure 2).

\section{Discussion}

This study provides the most comprehensive evaluation to date of genetic diversity and population structure for Yellowstone cutthroat trout in the upper Snake River basin. Our results suggest that genetic diversity was highly partitioned among all of the major river drainages. The NJ tree recognized a split between all 11 drainages, and all but four of the populations clustered with other populations from the same geographic region. The West Pine Creek and North Fork Rainey Creek populations clustered with populations from the adjacent Salt River drainage, although they were sampled within the South Fork Snake River drainage. Before 1957, populations in these drainages were connected through the South Fork Snake River. Currently, Palisades Dam Reservoir (completed in 1957) acts as a complete barrier to upstream passage. A genetic signal for isolation between these drainages as a result of genetic drift was probably obscured by the currently large populations of fish in both the Salt River and South Fork Snake River drainages (K. A. Meyer, unpublished data) and the possibility of downstream migration. The other two populations that did not cluster with their respective drainage (Mike Harris Creek and Mahogany Creek) were smaller and more isolated; therefore, genetic drift is probably influencing their placement in the NJ tree. A population may be erroneously grouped with other populations if, through genetic drift, it becomes fixed or nearly fixed for the most common allele of another population (Spruell et al. 2003). Despite these four anomalies, drainage-level differences suggest historical separation at a longer timescale.

In addition to drainage-level partitioning, we found that the degree of observed population differentiation varied widely within drainages. The populations 


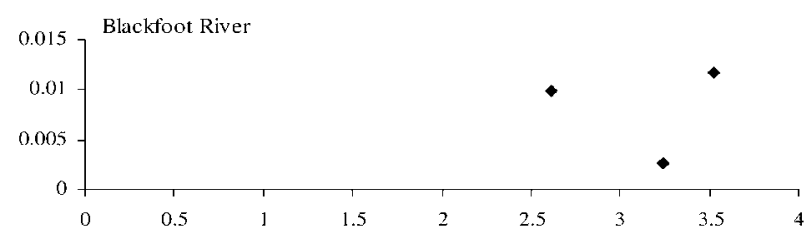

\section{Portneul River}
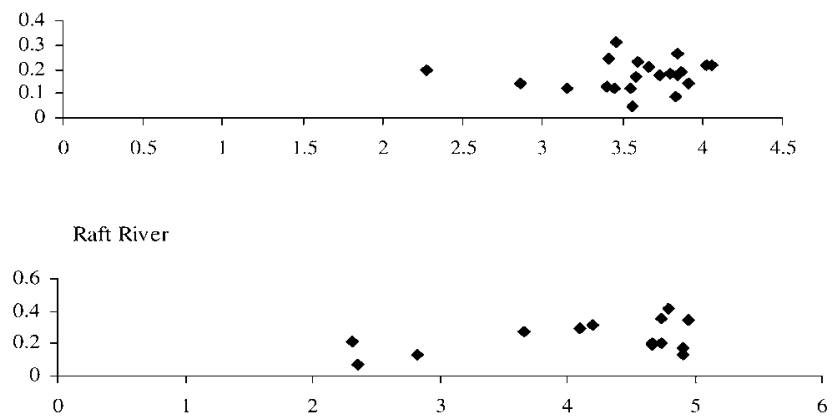

Salt River

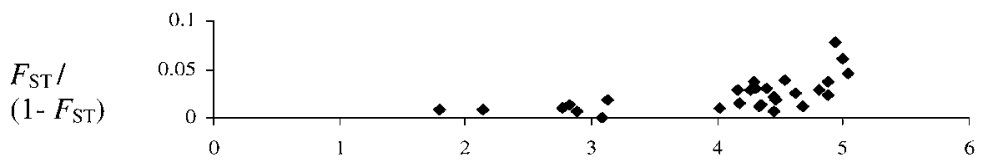

S. F. Snake River

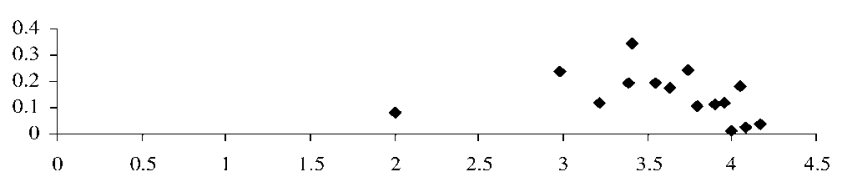

Teton River

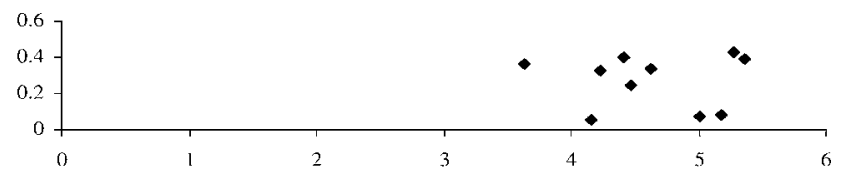

Willow Creek

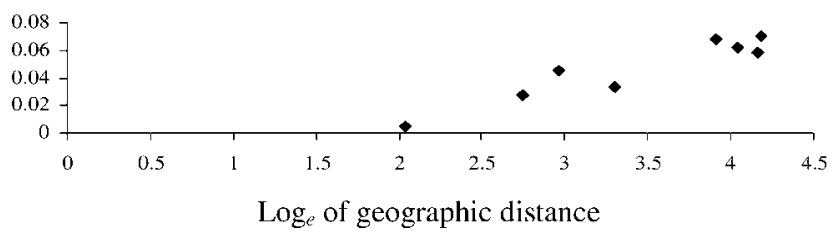

FIGURE 6.-Scatterplots of $F_{\mathrm{ST}} /\left(1-F_{\mathrm{ST}}\right)$ estimates versus the logarithm of fluvial geographic distance $(\mathrm{km})$ for each pair of Yellowstone cutthroat trout populations in the upper Snake River basin, Idaho, in 1999-2003, by drainage. 
sampled within the Blackfoot River, Willow Creek, and Salt River drainages were the least differentiated. The populations sampled within the Blackfoot River were separated by only $13 \mathrm{~km}$ to $33 \mathrm{~km}$ (Table 2). There was no relationship between geographic distance and genetic distance within this drainage, but this relationship may be nonsignificant because the geographic scale was not large enough to detect differentiation. In the Salt River and Willow Creek drainages, a significant positive relationship between genetic and geographic distance was observed across a larger scale (Table 2). Pairwise $F_{\mathrm{ST}}$ comparisons and the Bayesian assignment test revealed low levels of genetic differentiation at both low and high geographic distances and that gene flow has occurred not only between neighboring populations but among all of the sampled populations within these three drainages, although not as frequently among geographically distant populations.

Yellowstone cutthroat trout populations were more differentiated within the Raft River, Teton River, Portneuf River, and South Fork Snake River drainages. All of the populations in the Raft River and Portneuf River drainages along with Garden Creek and Fall Creek in the South Fork Snake River drainage were highly differentiated from adjacent populations at a similar or smaller spatial scale than observed in the Salt River drainage, while two populations (Mike Harris Creek and Mahogany Creek) in the Teton River drainage were more geographically separated. Population differentiation can result from reproductive isolation due to natal homing (Spruell et al. 1999) or barriers to movement, such as anthropogenic barriers (Taylor et al. 2003; Wofford et al. 2005) and habitat patchiness (Gowan and Fausch 1996), which reduce levels of gene flow and increase genetic drift. Populations within these drainages may be composed of resident-type fish. However, the Bayesian assignment test provided evidence that gene flow was occurring between some of these populations and that it was asymmetric in some cases. This pattern is most likely due to the presence of migration barriers. The Mantel test indicated that genetic drift was the primary influence for differentiation (despite some evidence of migration) and that many populations within these drainages appear to be disconnected from adjacent populations.

Geographic barriers can include both natural (e.g., waterfalls) and anthropogenic structures (large dams, water diversions, culverts, habitat fragmentation) and act similarly in promoting genetic differentiation by preventing upstream migration (Neville et al., in press). In the Teton River drainage, a hydroelectric dam (Felt Dam) prevents upstream migration to Mike Harris and
Mahogany Creek from the other sampled populations. Water diversions present in both of these streams probably limit connectivity as well. The population in North Moody Creek resides above a waterfall and an impassable irrigation diversion and is also isolated from the rest of the Teton River drainage. In the South Fork Snake River drainage, Garden Creek is isolated due to water diversions and habitat fragmentation, while the population in Fall Creek resides above a major waterfall. The lower end of North Fork Rainey Creek in the South Fork Snake River drainage is also diverted, and habitat has been drastically altered such that movement between North Fork Rainey Creek and other populations may only occur during high-water years. Displacement of native cutthroat trout by nonnatives in some reaches may also lead to a loss of connectivity (Griffith 1988). Our genetic data confirm that the populations mentioned above are not connected to adjacent populations and suggest that a combination of anthropogenic and natural barriers has resulted in reduced gene flow.

Efforts to store, control, and direct water have led to the decline of some populations of Yellowstone cutthroat trout in low-elevation (Gresswell 1995) and main-stem rivers (Thurow et al. 1997). The hydrologic integrity indices reported by Van Kirk and Benjamin (2001) were used to depict overall habitat conditions within each drainage in terms of impacts of water resource development (Table 2). The Salt River drainage had the highest rating for hydrologic integrity within the upper Snake River basin and may represent the least impacted habitat for Yellowstone cutthroat trout in Idaho. Our data indicated that gene flow was high throughout the Salt River drainage (in Idaho), suggesting that Yellowstone cutthroat trout populations will exchange migrants across large geographic areas given adequate habitat conditions. Conversely, natural hydrologic regimes in other drainages have been altered by different degrees from water withdrawals, reservoirs, and consumptive use (Van Kirk and Benjamin 2001; Table 2), and reduced gene flow was detected in the Teton River, South Fork Snake River, Portneuf River, and Raft River drainages. The Willow Creek and Blackfoot River populations were given lower overall hydrologic integrity values when compared with the Salt River drainage, but our data indicated that habitat fragmentation has not led to reduced gene flow at the sampled scale. Additional samples are needed across larger spatial and temporal scales to fully characterize genetic relationships and determine the level of threat that habitat alteration and fragmentation pose within these drainages.

The lack of genetic differentiation observed across the scale of the Salt River drainage is in contrast to 
what has been reported for other cutthroat trout using microsatellite markers. Previous studies of other cutthroat trout subspecies have revealed high levels of genetic differentiation between populations occupying streams in unimpacted habitats (Wenburg et al. 1998; Wenburg and Bentzen 2001; Young et al. 2004). These studies concluded that populations are subdivided at the individual stream level and that many partially independent populations occupy a single drainage. The range of genetic diversity observed in the Salt River drainage was similar or higher than levels reported in other studies (Wenburg et al. 1998; Spruell et al. 2003; Taylor et al. 2003; Young et al. 2004), suggesting there was sufficient power to detect genetic differentiation. Therefore, these data support the concept that Yellowstone cutthroat trout are structured at a drainage level within high-quality habitat, as originally proposed by Allendorf and Leary (1988).

A lack of differentiation at a river drainage scale could be the result of migration or a recent common ancestor. In the Yellowstone River basin, little genetic differentiation has been observed among local populations of Yellowstone cutthroat trout (Allendorf and Leary 1988; Leary et al. 1995). The relatively short time since colonization $(12,000$ years ago; Gresswell et al. 1994), lack of environmentally selective pressures, and dispersal have been cited as the major reasons for no detectable variation in this region (Gresswell et al. 1997). In contrast, Yellowstone cutthroat trout have inhabited the upper Snake River basin in Idaho for a longer time period (Behnke 1992). Therefore, little genetic differentiation at the scale observed in the Salt River, Blackfoot River, and Willow Creek drainages is probably the result of successful dispersal. Cutthroat trout have a propensity to move large distances (up to $50 \mathrm{~km}$ ) during spring, and this increased movement has been attributed to spawning (Thurow et al. 1988; Henderson et al. 2000). Although documented stray rates are low among cutthroat trout populations (Gresswell et al. 1997), few successful migrants are needed to homogenize populations (Mills and Allendorf 1996). Therefore, differences in the scale of differentiation observed among Yellowstone cutthroat trout compared with other cutthroat trout subspecies may be a reflection of successful dispersal of this subspecies in connected habitat.

Temporal variation can be equally as important as spatial variation (Kinnison et al. 2002). In this study, Tincup Creek sample collections yielded insignificant temporal variation across years, yet Harkness Creek sample collections yielded significant allele frequency differences. If temporal variation exceeds spatial variation, population structure may be an artifact of sampling error (Kinnison et al. 2002). In this study, temporal and spatial stability were still evident, since the Harkness Creek samples still clustered together in the NJ tree and Bayesian analysis and drainage-wide clustering was identified. Temporal variability observed within Harkness Creek is probably a result of the strong influence of genetic drift in the Portneuf River drainage compared with the Salt River drainage.

A relationship between levels of genetic diversity and gene flow was also detected. The populations in the Salt River drainage, which appear to exchange gene flow at the largest geographic scale, have significantly higher levels of genetic diversity compared with populations in other drainages. As populations within major drainages may have arisen from separate founding events (M. R. Campbell, unpublished data), it is difficult to infer that diversity levels were historically similar across the entire range of Yellowstone cutthroat trout; however, reduced genetic diversity was observed within isolated populations in the Raft River, Teton River, and South Fork Snake River drainages (e.g., Garden Creek, Fall Creek) compared with more connected populations within their respective drainage, which probably had a similar evolutionary history. A loss of diversity in these populations further suggests that gene flow is not large enough to counter the forces of genetic drift or selection and that some populations may be at risk of inbreeding depression and demographic and environmental stochasticity, which may eventually reduce population size without the possibility of natural recolonization.

Past stocking of hatchery-origin fish can alter the local genetic structure of natural populations. Both rainbow trout and hatchery-origin Yellowstone cutthroat trout have been released into the study area and may have impacted the genetic structure of local populations. While rainbow trout introgression was present in some of the sampled populations, the removal of all identified hybrids should have alleviated this problem. This methodology ensures that all pure rainbow trout and first-generation hybrids were excluded from the analyses, but some advancedgeneration hybrids may not have been detected. Wenburg et al. (1998) compared analyses of genetic structure with and without hybrids and reported that the inclusion of later-generation hybrids revealed only small quantitative differences in genetic structure. While precautions must be taken regarding allele frequencies in the hybridized populations, we believe the possible inclusion of later-generation hybrids should have had minimal effect.

In the Salt River drainage, stocking of hatcheryorigin Yellowstone cutthroat trout has occurred for 
decades (IDFG stocking database; available at http:// fishandgame.idaho.gov/fish/stocking/). In Tincup Creek, 2,000 catchables from Auburn Fish Hatchery are stocked annually (D. Scully, IDFG, personal communication), and in Palisades Reservoir, 250,000 fingerlings from Jackson National Fish Hatchery are stocked annually and have a high likelihood of moving into McCoy Creek when the reservoir is full (J. Fredericks, IDFG, personal communication). Stocking records also indicate that Crow Creek, McCoy Creek, and Stump Creek were stocked throughout the 1980s and early 1990s. Depending on the success of these stocking events, this may have homogenized allele frequencies among populations (Van Houdt et al. 2005). The rate of intraspecific introgression was not assessed since it would require baseline allele frequencies before stocking and a significant genetic signal among the hatchery stocks, which were founded from these wild populations. Based upon the apparent connectivity between all populations (not just a few) in the Salt River drainage, we believe it is unlikely that the connectivity we observed in the Salt River drainage is solely the result of introgression with hatchery cutthroat trout. The hydrologic integrity values further substantiate that movement corridors are intact. Nevertheless, precautions must be exercised regarding our conclusion of limited genetic differentiation within this drainage. Additional research on the Wyoming side of the Salt River drainage may resolve this uncertainty, although this area has been stocked with hatchery-origin Yellowstone cutthroat trout as well (D. Isaac, Rocky Mountain Research Station, personal communication).

\section{Management Implications}

The data presented in this study reveal several implications for management of Yellowstone cutthroat trout. First, populations within all drainages should be prioritized for conservation and management to ensure adequate representation of genetic variation. Second, where Yellowstone cutthroat trout are structured as panmictic units within less fragmented habitats (e.g., Salt River drainage in Idaho), populations can be managed as singular units. However, the designation of discrete management units based on a geographic scale is complicated by habitat fragmentation. Third, the high levels of genetic differentiation and associated low levels of genetic diversity among some populations in the Portneuf River, South Fork Snake River, Teton River, and Raft River drainages suggest that gene flow is limited in degraded habitats and that there is an overall decline in the migratory life history component. Populations that are smaller and more isolated are predicted to lose genetic diversity at a greater rate and are more at risk of inbreeding, reduced fitness, and localized extinctions (Lande 1993; Frankham 1996). The data presented in this study and other demographic data revealed that 10 of the sampled populations (Mike Harris Creek, Mahogany Creek, Goodenough Creek, Robbers Roost Creek, Harkness Creek, Gibson Jack Creek, Johnson Creek, Basin Creek, Garden Creek, Tyghee Creek) are small in size with fewer than 500 adult spawners (Meyer, unpublished data), have significantly lower levels of genetic diversity, and are isolated from adjacent populations. These data emphasize the importance of connected habitat to the maintenance of genetic diversity and the expression of all life history variation. Future management actions should include restorative habitat manipulations and improvements to reestablish connectivity among tributary and main-stem populations, where possible.

The restoration of historically connected streams may be impossible in some areas, given the realities of water development, extensive habitat fragmentation (Hilderbrand 2002), and invasions by nonnatives (Harig et al. 2000). Harig et al. (2000) revealed that $48 \%$ of failed establishment efforts for greenback cutthroat trout $O$. c. stomias were the result of reinvasion by nonnatives. Alternative strategies for reducing extinction risks in small, fragmented populations may include increasing carrying capacity by improving habitat quality and habitat length (Hilderbrand 2003) or by supplementing populations with wild fish from nearby populations and creating artificial migration (Hilderbrand 2002). Translocation of fish among major drainages is not recommended because of the large genetic differences observed among drainages, but instead should occur among adjacent populations within drainages, if necessary. Lastly, the detection of hybrids within some of the populations suggests that hybridization also needs to be evaluated before any proposed translocation and that this will also determine which groups of populations or individual populations are considered viable source populations. Supplementation may be logistically difficult in areas where there are few fish within source populations and may lead to reductions in effective population size and genetic diversity (Ryman and Laikre 1991; Policansky and Magnuson 1998). Because of the considered risks associated with either connectivity restoration or translocation, a relative risk assessment should be undertaken to determine appropriate near-term management actions to ensure the genetic viability of Yellowstone cutthroat trout in Idaho.

\section{Acknowledgments}

This project was funded by funds from Federal Aid in Sport Fish Restoration, Project F-73-R-20 and by the 
Bonneville Power Administration through intergovernmental contract 4261. We would like to thank personnel from IDFG for their work in collecting samples and for their help with laboratory work: Holly Lehman, Tony Lamansky, Steve Elle, and Liz Mamer. Tim Williams and Liz Mamer also provided geographical information systems assistance. We would like to thank Rob Van Kirk, Deborah Myers, Dan Schill, and Steve Yundt for providing earlier reviews of this manuscript.

\section{References}

Allendorf, F. W., and R. F. Leary. 1988. Conservation and distribution of genetic variation in a polytypic species, the cutthroat trout. Conservation Biology 2:170-182.

Allendorf, F. W., and R. S. Waples. 1996. Conservation and genetics of salmonid fishes. Pages 238-273 in J. C. Avise and J. L. Hamrick editors. Conservation genetics: case histories from nature. Chapman and Hall, New York.

Baker, J., P. Bentzen, and P. Moran. 2002. Molecular markers distinguish coastal cutthroat trout from coastal rainbow trout/steelhead and their hybrids. Transactions of the American Fisheries Society 131:404-417.

Ball, O. P. 1955. Some aspects of homing in cutthroat trout. Proceedings of the Utah Academy of Sciences, Arts, and Letters 32:75-80.

Banks, M. A., V. K. Rashbrook, M. J. Calavetta, C. A. Dean, and D. Hedgecock. 2000. Analysis of microsatellite DNA resolves genetic structure and diversity of Chinook salmon (Oncorhynchus tshawytscha) in California's Central Valley. Canadian Journal of Fisheries and Aquatic Sciences 57:915-927.

Beacham, T. D., M. Lapointe, J. R. Candy, K. R. Miller, and R. E. Withler. 2004. DNA in action: rapid application of DNA variation to sockeye salmon fisheries management. Conservation Genetics 5:411-416.

Behnke, R. J. 1992. Native trout of western North America. American Fisheries Society, Monograph 6, Bethesda, Maryland.

Benson, N. G. 1960. Factors influencing production of immature cutthroat trout in Arnica Creek, Yellowstone Park. Transactions of the American Fisheries Society 89:168-175.

Campbell, M. R., J. Dillon, and M. S. Powell. 2002. Hybridization and introgression in a managed, native population of Yellowstone cutthroat trout: genetic detection and management implications. Transactions of the American Fisheries Society 131:364-375.

Cavalli-Sforza, L. L., and A. W. F. Edwards. 1967. Phylogenetic analysis: models and estimation procedures. Evolution 32:550-570.

Clancy, C. G. 1988. Effects of dewatering on spawning by Yellowstone cutthroat trout in tributaries to the Yellowstone River, Montana. Pages 37-41 in R. E. Gresswell, editor. Status and management of interior stocks of cutthroat trout. American Fisheries Society, Symposium 4, Bethesda, Maryland.

Condrey, M. J., and P. Bentzen. 1998. Characterization of coastal cutthroat trout (Oncorhynchus clarki clarki) microsatellites and their conservation in other salmonids. Molecular Ecology 7:783-792.

Dingle, H. 1996. Migration: the biology of life on the move. Oxford University Press, New York.

Epifanio, J., H. Gordon, P. Karen, B. Rieman, P. Spruell, C. Stockwell, F. Utter, and W. Young. 2003. Integrating conservation genetic considerations into conservation planning: a case study of bull trout in the Lake Pend Oreille-lower Clark Fork River system. Fisheries 15(8):10-24.

Excoffier, L., P. E. Smouse, and J. M. Quattro. 1992. Analysis of molecular variance inferred from metric distances among DNA haplotypes: application to human mitochondrial DNA restriction data. Genetics 131:479-491.

Frankham, R. 1996. Relationship of genetic variation to population size in wildlife. Conservation Biology 10:1500-1508.

Goudet, J. 2001. FSTAT: a program to estimate and test gene diversities and fixation indices, version 2.9.3. Available: http://www.unil.ch/izea/softwares/fstat.html.

Goudet, J., M. Raymond, T. de Meeüs, and F. Rousset. 1996. Testing differentiation in diploid populations. Genetics 144:1933-1940

Gowan, C., and K. D. Fausch. 1996. Long-term demographic responses of trout populations to habitat manipulation in six Colorado streams. Ecological Applications 6:931946.

Gresswell, R. E. 1995. Yellowstone cutthroat trout. U.S. Forest Service General Technical Report RM-GTR256:36-54.

Gresswell, R. E., W. J. Liss, and G. L. Larson. 1994. Life history organization of Yellowstone cutthroat trout in Yellowstone Lake. Canadian Journal of Fisheries and Aquatic Sciences 51:298-309.

Gresswell, R. E., W. J. Liss, G. L. Larson, and P. J. Bartlein. 1997. Influence of basin- scale physical variables on life history characteristics in Yellowstone Lake. North American Journal of Fisheries Management 17:10461064 .

Griffith, J. S. 1988. Review of competition between cutthroat trout and other salmonids. Pages $134-140$ in R. E. Gresswell, editor. Status and management of interior stocks of cutthroat trout. American Fisheries Society, Symposium 4, Bethesda, Maryland.

Harig, A. L., K. D. Fausch, and M. K. Young. 2000. Factors influencing success of greenback cutthroat trout translocations. North American Journal of Fisheries Management 20:994-1004.

Hedrick, P. W. 1999. Perspective: highly variable loci and their interpretation in evolution and conservation. Evolution 53:313-318.

Henderson, R., J. L. Kershner, and C. A. Toline. 2000. Timing and location of spawning by nonnative wild rainbow trout and native cutthroat trout in the South Fork Snake River, Idaho, with implications for hybridization. North American Journal of Fisheries Management 20:584-596.

Hilderbrand, R. H. 2002. Simulating supplementation strategies for restoring and maintaining stream resident cutthroat trout populations. North American Journal of Fisheries Management 22:879-887.

Hilderbrand, R. H. 2003. The roles of carrying capacity, immigration, and population synchrony on persistence of 
stream resident cutthroat trout. Biological Conservation 110:257-266.

Hughes, C. R., and D. C. Queller. 1993. Detection of highly polymorphic loci in a species with little allozyme polymorphism. Molecular Ecology 2:131-137.

Hutchinson, D. W., and A. R. Templeton. 1999. Correlation of pairwise genetic and geographic distance measures: inferring the relative influences of gene flow and genetic drift on the distribution of genetic variability. Evolution 53:1898-1914.

Kanda, N., and F. W. Allendorf. 2001. Genetic population structure of bull trout from the Flathead River basin as shown by microsatellites and mitochondrial DNA markers. Transactions of the American Fisheries Society 130:92-106.

King, T. L., S. T. Kalinowski, W. B. Schill, A. P. Spidle, and B. A. Lubinski. 2001. Population structure of Atlantic salmon: a wide-range perspective from microsatellite DNA variation. Molecular Ecology 10:807-821.

Kinnison, M. T., P. Bentzen, M. J. Unwin, and T. P. Quinn. 2002. Reconstructing recent divergence: evaluating nonequilibrium population structure in New Zealand chinook salmon. Molecular Ecology 11:739-754.

Knudsen, K. L., C. C. Muhlfeld, G. K. Sage, and R. F. Leary. 2002. Genetic structure of Columbia River redband trout populations in the Kootenai River drainage, Montana, revealed by microsatellite and allozyme loci. Transactions of the American Fisheries Society 131:10931105.

LaBar, G. W. 1971. Movement and homing of cutthroat trout (Salmo clarki) in Clear and Bridge creeks, Yellowstone National Park. Transactions of the American Fisheries Society 100:41-49.

Lande, R. 1993. Risks of population extinction from demographic and environmental stochasticity and random catastrophes. American Naturalist 142:911-927.

Langella, O. 2001. Populations 1.2.24: population genetic structure (individuals or populations distances, phylogenetic trees). Available: http://www.pge.cnrs.gif.fr/ bioinfo/populations/.

Leary, R. F., F. W. Allendorf, and G. K. Sage. 1995. Hybridization and introgression between introduced and native fish. Pages 91-101 in Schramm L Jr. and R. G. Piper editors. Uses and effects of cultured fishes in aquatic ecosystems. American Fisheries Society, Symposium 15, Bethesda, Maryland.

Mantel, N. 1967. The detection of disease clustering and generalized regression approach. Cancer Research 27:209-220.

Meka, J. M., E. E. Knudsen, D. C. Douglas, and R. B. Benter. 2003. Variable migratory patterns of different adult rainbow trout life history types in a Southwest Alaska watershed. Transactions of the American Fisheries Society 132:717-732.

Miller, R. B. 1954. Comparative survival of wild and hatchery-reared cutthroat trout in a stream. Transactions of the American Fisheries Society 83:120-130.

Mills, S. L., and F. W. Allendorf. 1996. The one-migrant-pergeneration rule in conservation and management. Conservation Biology 10:1509-1518.

Nelson, R. J., and T. D. Beacham. 1999. Isolation and cross- species amplification of microsatellite loci useful for study of Pacific salmon. Animal Genetics 30:228-229.

Neville, H., J. Dunham, and M. Peacock. In press. Assessing connectivity in salmonid fishes with DNA microsatellite markers. in K. Crooks, and M. A. Sanjayan, editors. Connectivity conservation: maintaining connections in nature. Cambridge University Press, Boston.

Neville-Arsenault, H. 2003. Genetic assessment of complex dynamics in an interior salmonid metapopulation. Doctoral dissertation. University of Nevada, Reno.

Olsen, J. B., P. Bentzen, and J. E. Seeb. 1998. Characterization of seven microsatellite loci derived from pink salmon. Molecular Ecology 7:1087-1089.

Olsen, J. B., J. L. Miller, W. J. Spearman, and J. K. Wenburg. 2003. Patterns of intraspecific and interspecific genetic diversity in coho salmon: implications for conservation. Conservation Genetics 4:557-569.

Ostberg, C. O., and R. J. Rodriguez. 2002. Novel microsatellite markers differentiate Oncorhynchus mykiss (rainbow trout and steelhead) and the $O$. clarki (cutthroat trout) subspecies. Molecular Ecology Notes 2:197-202.

Ostberg, C. O., and R. J. Rodriguez. 2004. Bi-parentally inherited species-specific markers identify hybridization between rainbow trout and cutthroat trout subspecies. Molecular Ecology Notes 4:26-29.

Ostberg, C. O., S. L. Slatton, and R. J. Rodriguez. 2004. Spatial partitioning and asymmetric hybridization among sympatric coastal steelhead trout (Oncorhynchus mykiss irideus), coastal cutthroat trout $(O$. clarki clarki), and interspecific hybrids. Molecular Ecology 13:2773-2788.

Page, R. D. M. 1996. TREEVIEW: an application to display phylogenetic trees on personal computers. Computer Applications in the Biosciences 12:357-358.

Paragamian, V. L., M. S. Powell, and J. C. Faler. 1999. Mitochondrial DNA analysis of burbot stocks in the Kootenai River basin of British Columbia, Montana, and Idaho. Transactions of the American Fisheries Society 128:868-874.

Policansky, D., and J. J. Magnuson. 1998. Genetics, metapopulations, and ecosystem management of fisheries. Ecological Applications 8:S119-S123.

Pritchard, J. K., and M. Stephens. and P. Donnelly. 2000. Inferences of population structure using multilocus genotype data. Genetics 155:945-959.

Raymond, M., and F. Rousset. 1995. GENEPOP, version 1.2: a population genetics software for exact tests and ecumenicism. Journal of Heredity 86:248-249.

Rexroad, C. E. III, R. L. Coleman, A. L. Gustafson, W. K. Hershberger, and J. Killefer. 2002. Development of rainbow trout microsatellite markers from repeat-enriched libraries. Marine Biotechnology 3:12-16.

Rice, W. R. 1989. Analyzing tables of statistical tests. Evolution 43:223-225.

Rieman, B. E., and J. B. Dunham. 2000. Metapopulations and salmonids: a synthesis of life history patterns and empirical observations. Ecology of Freshwater Fish 9:51-64.

Roques, S., J.-M. Sevigny, and L. Bernatchez. 2001. Evidence for broad-scale introgressive hybridization between two redfish (genus Sebastes) in the Northwest Atlantic: a rare marine example. Molecular Ecology 10:149-165.

Ryman, N., and L. Laikre. 1991. Effects of supportive 
breeding on the genetically effective population size. Conservation Biology 5:325-329.

Sakamoto, T., N. O. Okamoto, Y. Ikeda, Y. Nakamura, and T. Sato. 1994. Dinucleotide- repeat polymorphism in DNA of rainbow trout and its application in fisheries science. Journal of Fish Biology 4:1093-1096.

Schneider, S., D. Roessli, and L. Excoffier. 2000. Arlequin, version 2.0: a software for population genetic data analysis. Genetics and Biometry Laboratory, University of Geneva, Geneva, Switzerland.

Spruell, P., A. R. Hemmingsen, P. J. Howell, N. Kanda, and F. W. Allendorf. 2003. Conservation genetics of bull trout: geographic distribution of variation at microsatellite loci. Conservation Genetics 4:17-29.

Spruell, P., B. E. Rieman, K. L. Knudsen, F. M. Utter, and F. W. Allendorf. 1999. Genetic population structure within streams: microsatellite analysis of bull trout populations. Ecology of Freshwater Fish 8:114-121.

Taylor, E. B., M. D. Stamford, and J. S. Baxter. 2003. Population subdivision in westslope cutthroat trout (Oncorhynchus clarki lewisi) at the northern periphery of its range: evolutionary inferences and conservation implications. Molecular Ecology 12:2609-2622.

Tessier, N., L. Bernatchez, P. Presa, and B. Angers. 1995. Gene diversity analysis of mitochondrial DNA, microsatellites, and allozymes in landlocked Atlantic salmon. Journal of Fish Biology (Supplement A):156-163.

Thurow, R. F., C. E. Corsi, and V. K. Moore. 1988. Status, ecology, and management of Yellowstone cutthroat trout in the upper Snake River drainage, Idaho. Pages 25-36 in R. E. Gresswell, editor. Status and management of interior stocks of cutthroat trout. American Fisheries Society, Symposium 4, Bethesda, Maryland.

Thurow, R. F., D. C. Lee, and B. E. Rieman. 1997. Distribution and status of seven native salmonids in the interior Columbia River basin and portions of the Klamath River and great basins. North American Journal of Fisheries Management 17:1094-1110.

USFWS (U.S. Fish and Wildlife Service). 2003. Endangered and threatened wildlife and plants: reconsidered finding for an amended petition to list the westslope cutthroat trout as threatened throughout its range. Federal Register 66:46989-47009.

Van Houdt, J. K. J., J. Pinceel, M.-C. Flamand, M. Briquet, E. Dupont, F. A. M. Volckaert, and P. W. Baret. 2005. Migration barriers protect indigenous brown trout (Salmo trutta) populations from introgression with stocked hatchery fish. Conservation Genetics 6:175-191.

Van Kirk, R. W., and L. Benjamin. 2001. Status and conservation of salmonids in relation to hydrologic integrity in the Greater Yellowstone ecosystem. Western North American Naturalist 61:359-374.

Varley, J. D., and R. E. Gresswell. 1988. Ecology, status, and management of the Yellowstone cutthroat trout. Pages 13-24 in R. E. Gresswell, editor. Status and management of interior stocks of cutthroat trout. American Fisheries Society, Symposium 4, Bethesda, Maryland.

Verhulst, S., and H. M. van Eck. 1996. Gene flow and immigration rate in an island population of great tits. Journal of Evolutionary Biology 9:771-782.

Weir, B. S., and C. C. Cockerham. 1984. Estimating Fstatistics for the analysis of population structure. Evolution 38:1358-1370.

Wenburg, J. K., and P. Bentzen. 2001. Genetic and behavioral evidence for restricted gene flow among coastal cutthroat trout populations. Transactions of the American Fisheries Society 130:1049-1069.

Wenburg, J. K., P. Bentzen, and C. J. Foote. 1998. Microsatellite analysis of genetic population structure in an endangered salmonid: the coastal cutthroat trout (Oncorhynchus clarki clarki). Molecular Ecology 7:733-749.

Wofford, J. E. B., R. E. Gresswell, and M. A. Banks. 2005. Influence of barriers to movement on within-watershed genetic variation of coastal cutthroat trout. Ecological Applications 15:628-637.

Young, S. F., J. G. McLellan, and J. B. Shaklee. 2004. Genetic integrity and microgeographic population structure of westslope cutthroat trout, Oncorhynchus clarki lewisi, in the Pend Oreille basin in Washington. Environmental Biology of Fishes 69:127-142. 